\title{
Efficacy and Selectivity of Pre-Emergence Herbicide S- Metolachlor Against Annual Grass and Broad Leaved Weeds in Faba Bean
}

\author{
Kassahun Zewdie*, Kiflom Yohannes \\ Ethiopian Institute of Agricultural Research, Holetta Research Center, P.O.Box. 2003, Addis Abeba, Ethiopia \\ *Corresponding Author: Kassahun Zewdie, Ethiopian Institute of Agricultural Research, Holetta \\ Research Center, P.O.Box. 2003, Addis Abeba, Ethiopia
}

\begin{abstract}
A field trial was conducted at Holetta research center and farmers' fields during 2016/17 and $2017 / 18$ to determine the effectiveness of S-metolachlor herbicide application on annual grasses and broad leaved weeds in faba bean. The experiment consisted of six treatments; S-metolachlor (1.0, 1.5 Lha $^{-1}$ alone and S-metolachlor 1.0, $1.5 \mathrm{Lha}^{-1}$ supplemented one hand weeding (25-30 days after crop emergence), farmers' practice twice hand weeding (25-30 and 55-60 days after crop emergence) and weedy checks arranged in randomized complete block design. The faba bean variety used was Dosha and the recommended fertilizer rate was applied. The herbicide was applied single pre emergence (1-3) days after planting using manual knapsack sprayer with a water volume of $200 \mathrm{Lha}^{-1}$ rates for each plot. The result exhibited that pre emergence application of S-metolachlor @ 1.0 and 1.5 Lha $^{-1}$ had a significant $(P<0.05)$ effect on broad leaved and grass weeds; Polygonum nepalensis, Corrigiola capensis, Plantago lanceolata, Caylusea abyssinica, Spergula arvensis, Raphanus raphanistrum, Bidens pilosa, Galinsoga parviflora, Oxalis latifolia, and Guizotia scabra, Snowdenia polystachya, Setaria pumlia, Phalaris paradoxa and Avena fatua for a prolonged time after application and their density was significantly reduced. Between treatments significant differences of yield, plant height and seeds per plant was attained. The highest grain yield (2770 $\left.\mathrm{kg} \mathrm{ha}^{-1}\right)$ was achieved from twice hand weeding followed by S-metolachlor 1.0 and $1.5 \mathrm{Lha}^{-1}$ supplemented one hand weeding (2540, $\left.2502 \mathrm{~kg} \mathrm{ha}^{-1}\right)$. The yield advantages were 64.8, 61.6 and 61.0\% over the unweeded check.
\end{abstract}

Keywords: S-metolachlor, effectiveness, faba bean, weeds

Abbreviations: CSA: Central Statistical Authority, SAS: Statistical Analysis System

\section{INTRODUCTION}

In Ethiopia, faba bean is the major food legumes grown for human consumption, as green pods or dry seeds, as well as for animal feed and use for soil fertility replenishment. Faba bean (Vicia faba L.) is the most important and widely grown among pulse crop in Ethiopia it covers about 459000 ha of land with a total production of 0.58 million tons every year (CSA, 2017). It is the most important and widely grown pulse crop, accounting for about $58 \%$ of the area covered by food legumes in southern Ethiopia [1]. However the yields remain very low due to several constraints, one of the major constraints to faba bean production are weeds. Faba bean is very sensitive to weed competition particularly at its early growing stage to early flowering stage; yield loss of 20-95\% was recorded in Ethiopia [2,3]. This is mainly because of farmers' belief that weeds have no influence on legumes [4]. Twice hand-weeding (four and seven weeks after planting) are recommended to control the weeds in faba bean [2]. But these operations were found laborious, time and energy consuming and least preferred by farmers due to labor resource limitations. So far, little information is available on the response of faba bean to alternative herbicides. Therefore, the purpose of this study was to examine the effect of S-metolachlor efficiency on performance against commonly problematic annual grasses and broad leaf weeds in faba bean.

\section{MATERIAL AND METHODS}

\subsection{Site Description}

The experiment was conducted at Holetta Research center and farmers field during the main cropping season of 2016/17 and 2017/ 2018. At both locations, the average monthly mean minimum 
temperature during the crop growing season are $6.4^{\circ} \mathrm{c}$ and $11.5^{\circ} \mathrm{c}$ the corresponding average monthly mean maximum temperature are $21.3^{\circ} \mathrm{c}$ and $23.8^{\circ} \mathrm{c}$ with total rainfall of 924.5 and $580 \mathrm{~mm}$, respectively. All locations had been under conventional management practices of plowing, disking and harrowing for last many years.

\subsection{Treatments, Experimental Design and Procedure}

The experiment consisted of five treatments in three sites (HRC and on two different farmers' fields). The trial was laid out in a randomized complete block design (RCBD) with three replications for each site in a plot size of $4 \mathrm{~m} \times 5 \mathrm{~m}^{2}$.

\begin{tabular}{|c|c|}
\hline Treatment code & Detail \\
\hline 1 & S-metolachlor $1.0 \mathrm{Lha}^{-1}$ \\
\hline 2 & S-metolachlor $1.0 \mathrm{Lha}^{-1}+\mathrm{HW}$ \\
\hline 3 & S-metolachlor $1.5 \mathrm{Lha}^{-1}$ \\
\hline 4 & S-metolachlor $1.5 \mathrm{Lha}^{-1}+\mathrm{HW}$ \\
\hline 5 & HW X 2 $(25-30,55-60)$ \\
\hline 6 & Untreated control \\
\hline
\end{tabular}

$H W=$ Hand Weeding

The experimental field was ploughed twice using tractor mounted plough and the plots were leveled manually. Planting of Faba bean was done by drilling the seeds at $40 \mathrm{~cm}$ wide rows at a rate of $200 \mathrm{~kg}$ $\mathrm{ha}^{-1}$. The Faba bean variety used was Dosha. Recommended fertilizer rate was drilled in furrows at planting. The herbicides were applied single pre emergence application immediately after sowing or before emergence using manual knapsack sprayer with a water volume of $200 \mathrm{~L} \mathrm{ha}^{-1}$ rate for each plot.

\subsection{Data Collection}

Weed density was taken twice (at the time of first and second hand weeding) for each individual weed species from each plot using $0.25 \mathrm{~m}^{2}$ quadrats four times. The weed species found within the sample quadrat were identified, counted and expressed in $\mathrm{m}^{2}$. Individual and general weed control scores were also taken four weeks after herbicide application, first and second hand weeding and at the time of harvest. At harvest the weeds were cut near the soil surface and placed in an oven at $65^{\circ} \mathrm{c}$ temperature till constant weight and their dry weight was measured. The dry weight was expressed in $\mathrm{gm}^{-2}$. The data on weed density and dry matter were subjected to $\sqrt{\mathrm{x}}+0.5$ transformations before analysis.

Weed control efficiency: $W C E=\frac{(W D C-W D T)}{W D C} \times 100$

Where: WCE=Weed Control Efficiency, WDC= Weed Dry mater in weedy check,

WDT $=$ Weed Dry Matter in particular treatment

Plant height was measured from 4 randomly selected plants in each plot. Hundred seeds were counted randomly and their weight was measured at $10 \%$ grain moisture content. Grain yield was also measured after threshing the sun dried plants harvested from each plot and adjusted at $10 \%$ grain moisture content.

Partial budget analysis was calculated by taking in to account the additional input cost (the labor cost for hand weeding, harvesting, threshing and winnowing) and gross returns obtained from different weed control treatments.

\section{Statistical analysis}

Finally, all data were subjected to analysis of variance following a procedure appropriate to the design of the experiment using SAS statistical software [5]. The treatment means that were significantly different at 5\% levels of significance were separated using Duncan Multiple Range Test (DMRT).

\section{RESULTS AND DISCUATION}

The experimental field was found to be infested with different types of grasses and broad leaved weeds (Table 1). The most dominant broad leaved weeds include Polygonum nepalensis, Corrigiola 
Efficacy and Selectivity of Pre-Emergence Herbicide S- Metolachlor Against Annual Grass and Broad Leaved Weeds in Faba Bean

capensis, Plantago lanceolata, Caylusea abyssinica, Spergula arvensis, Raphanus rephanistrum, Bidens pilosa, Galinsoga parviflora, Oxalis latifolia, and Guizotia scabra. Among the grass weeds Snowdenia polystachya, Setaria pumlia, Phalaris paradoxa and Avena fatua were dominant.

Table1. The major problematic weeds in the experimental fields during 2016/17 and 2017/18 cropping season.

\begin{tabular}{|c|c|}
\hline Botanical name & Family \\
\hline Bidens pilosa L., & Composite \\
Galinsoga parviflora, & Composite \\
Guzotia scabra & Composite \\
\hline Raphanus raphanistrum & Brassicaceae \\
\hline Corrigiola capensis, & Caryophyllaceae \\
Spergula arvensis & Caryophyllaceae \\
\hline Oxalis latifolia & Oxalidaceae \\
\hline Plantago lanceolata L. & Plntaginaceae \\
\hline Snowdenia polystachya, & Poaceae \\
Setaria pumlia, & Poaceae \\
Phalaris paradoxa L., & Poaceae \\
Avena fatua & Poaceae \\
\hline Polygonum nepalensis & Polygonaceae \\
\hline Caylusea abyssinica(Fressen.)Fisch.\& May & Resedaceae \\
\hline
\end{tabular}

Weeds density $\left(\mathrm{m}^{-2}\right)$ was significantly affected by S-metolachlor herbicide which reduced the weed population from $88-97 \%$ (Table-2). The highest number $\left(1250 \mathrm{~m}^{-2}\right)$ was recorded in weedy check; while the lowest $(30,50$ and 65$) \mathrm{m}^{-2}$ was detected with twice hand weeding followed by application of S-metolachlor 1.0 and $1.5 \mathrm{Lha}^{-1}+$ hand weeding.

Table2. Effect of weed control treatments on weed density $m^{-2}$

\begin{tabular}{|c|c|c|c|}
\hline Treatments & Broad leaved weeds & Grasses & Total \\
\hline S-metolachlor $1.0 \mathrm{Lha}^{-1}$ & 138 & 11 & 149 \\
\hline S-metolachlor $1.0 \mathrm{Lha}^{-1}+\mathrm{HW}$ & 47 & 3 & 50 \\
\hline S-metolachlor $1.5 \mathrm{Lha}^{-1}$ & 122 & 9 & 131 \\
\hline S-metolachlor $1.5 \mathrm{Lha}^{-1}+\mathrm{HW}$ & 51 & 14 & 65 \\
\hline HW X2 (25-30, 55-60) & 26 & 4 & 30 \\
\hline Untreated control & 1124 & 126 & 1250 \\
\hline
\end{tabular}

Dry weight of weeds biomass: The data on above ground dry weight biomass of weeds showed significant difference among the treatments at $\mathrm{p} \leq 0.05$. At harvest the highest total weeds biomass $\left(560.3 \mathrm{~g} \mathrm{~m}^{-2}\right)$ was recorded in weedy check, while, the lowest weeds biomass $\left(57.9\right.$ and $\left.64.6 \mathrm{gm}^{-2}\right)$ was observed with application S- metolachlor $1.0 \mathrm{~L} \mathrm{ha}^{-1}+$ one hand weeding and twice hand weeding treatments. All the weed control treatments significantly reduced the weed infestation (weed dry matter) and increased the yield of faba bean when compared with the control (unweeded check) (Table 3).

Table3. Effect of weed control treatments on weed dry weight at harvest (gms).

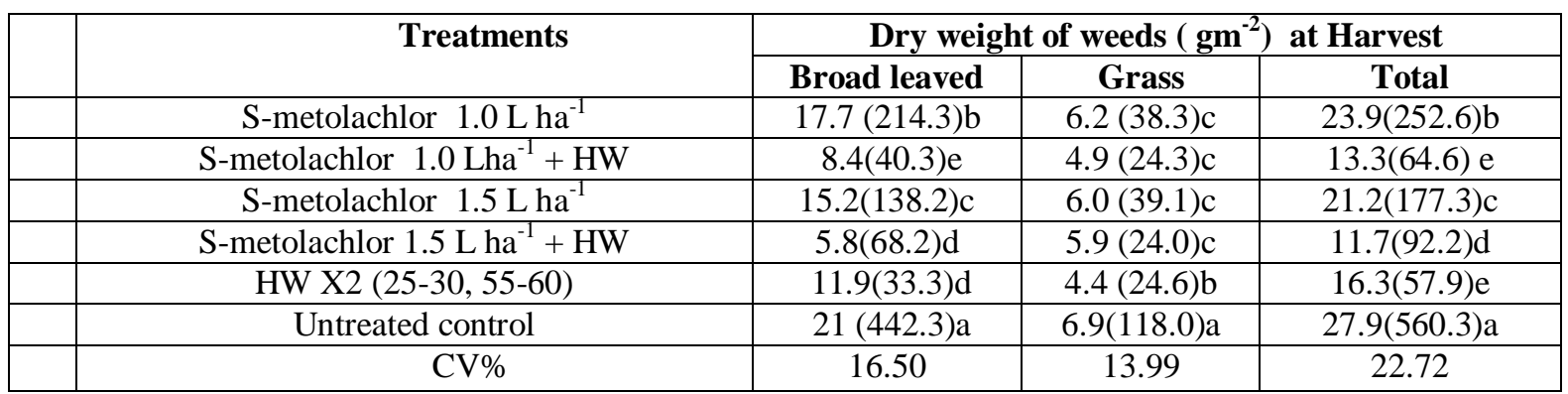

\subsection{Weed Control Efficiency}

Weed control efficiency (\%) was affected significantly by different rates of S-metolachlor herbicide. The maximum weed control efficiency was recorded in twice hand weeding plot (98\%) followed by smetolachlor at $1.5 \mathrm{kgha}^{-1}$ plus one hand weeding (95\%) and s-metolachlor at $1.0 \mathrm{kgha}^{-1}$ plus one hand weeding $(92 \%)$. While, the lowest weed control efficiency was recorded in weedy check $(0)$. The 
result is in agreement with the findings of [6] who reported that pre-emergent herbicides gave higher weed control efficiency by reducing the weed density and dry weight significantly as compared to weedy check (Figure 1).

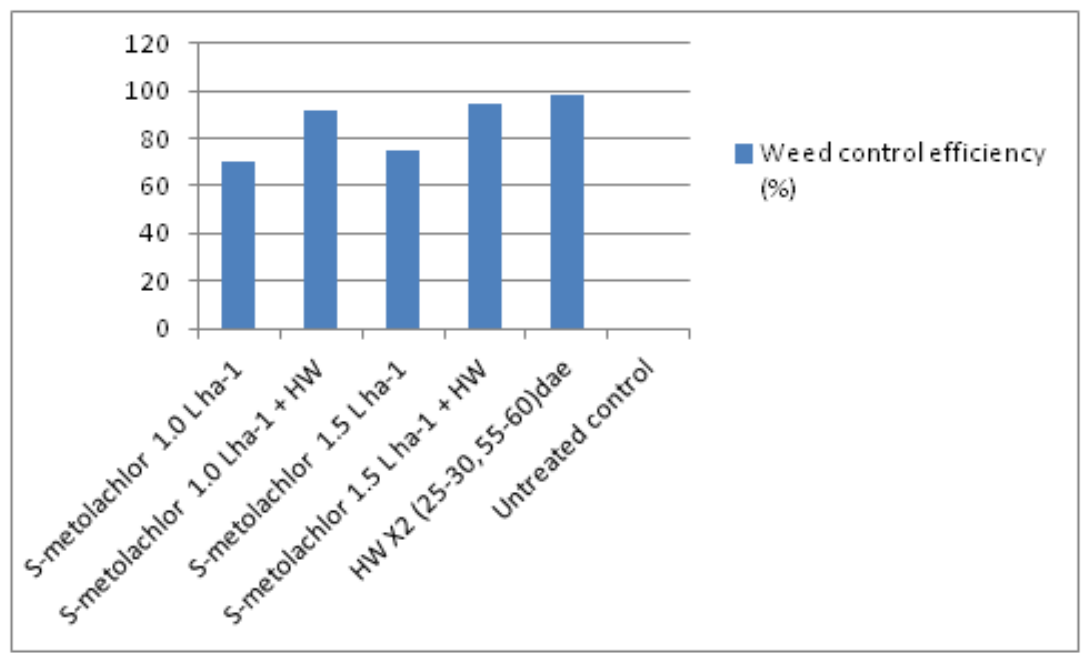

Figure1. Effect of weed control treatments on weed control efficiency

\subsection{Yield Components and Yield}

Plant height: The maximum height $(146.7 \mathrm{~cm})$ was recorded from two hand weeding treatment which did not significantly vary with plots treated S-metolachlor. The weedy check plot had plants with lowest height $(127.1 \mathrm{~cm})$ that was due to the impact of weeds on the growth and development of faba bean.

Hundred seed weight the data showed that the highest and lowest hundred seed weight was attained in two hand weeding and weedy check treatments respectively which were statistically insignificant among treatments.

Grain yield data revealed that significance difference among weed control treatments. The analysis of variance indicated that the highest grain yield $\left(2770 \mathrm{~kg} \mathrm{ha}^{-1}\right)$ was resulted from two hand weeding treatments that performed best and significantly vary from the weedy check plot but not statistically differ with S-metolachlor 1.5 $\mathrm{L} \mathrm{ha}^{-1}+$ one hand weeding and S-metolachlor $1.0 \mathrm{~L} \mathrm{ha}^{-1}+$ one hand weeding. Statistically in significant yield differences $\left(2540\right.$ and $\left.2502 \mathrm{~kg} \mathrm{ha}^{-1}\right)$ was perceived from Smetolachlor $1.0 \mathrm{~L} \mathrm{ha}^{-1}$ and $1.5 \mathrm{~L} \mathrm{ha}^{-1}$ alone applied plots. Two hand weeding treatment has a yield advantage (9 and $8 \%$ ) over S-metolachlor $1.0 \mathrm{~L} \mathrm{ha}^{-1}$ and $1.5 \mathrm{Lha}^{-1}$ supplemented with one hand weeding respectively $[8,9]$. Comparable result obtained in plant height, pods per plant, number of seeds per pod, 100 seed weight between treatments. Treatments effect was highly significant for the grain yield increased by $64.8 \%$ over the unweeded control plot. It was found that the results agreed with the study of many researchers (Table 5) $[7,8,9,10]$.

Table5. Effect of weed control treatments on yield and yield attributes of faba bean

\begin{tabular}{|c|c|c|c|c|c|c|}
\hline Treatments & PH(cm) & $100 \mathrm{SW}$ (gms) & NPPP & NSPP & NSPP & GY $\left(\mathrm{kg} \mathrm{ha}^{-1}\right)$ \\
\hline S-metolachlor $1.0 \mathrm{Lha}^{-1}$ & 143.0 & 80.2 & 10.2 & 22.2 & 2.4 & $2170 \mathrm{~b}$ \\
\hline S-metolachlor 1.0 $\mathrm{Lha}^{-1}+\mathrm{HW}$ & 144.1 & 82.0 & 10.4 & 24.6 & 2.6 & $2502 \mathrm{ab}$ \\
\hline S-metolachlor $1.5 \mathrm{Lha}^{-1}$ & 145.2 & 80.1 & 9.8 & 24.1 & 2.2 & $2080 \mathrm{~b}$ \\
\hline S-metolachlor $1.5 \mathrm{Lha}^{-1}+\mathrm{HW}$ & 141.3 & 81.7 & 12.3 & 26.2 & 2.5 & $2540 \mathrm{ab}$ \\
\hline HW X2 (25-30, 55-60) & 146.7 & 84.0 & 12.1 & 26.6 & 2.7 & $2770 \mathrm{a}$ \\
\hline Unweeded (control) & 127.1 & 74.9 & 9.7 & 18.6 & 2.3 & $975 c$ \\
\hline
\end{tabular}

$\mathbf{H W}=$ Hand weeding $; \mathbf{P H}=$ Plant Height $; \quad \mathbf{N S P P}=$ no of seeds per pod ; $\mathbf{N P P P}=$ number of pods per plant; $100 \mathrm{SW}=100$ seed weight; $\mathbf{N S P P}=$ number of seeds per plant ; $\mathbf{G Y}=$ grain weight; Values followed by the same letter are not significantly different at the $5 \%$ level of the LSD test.

\subsection{Partial Budget Analysis}

The result of the partial budget analysis showed that the highest total variable coast was recorded from two hand weeding (42174.00 Birr ha ${ }^{-1}$ ) followed by S-metolachlor $1.0 \mathrm{~L} \mathrm{ha}^{-1}$ plus one hand 
weeding and S-metolachlor $1.5 \mathrm{~L} \mathrm{ha}^{-1}$ supplemented with one hand weeding four weeks after planting resulted in the highest grain yield and economic benefit. This finding has an agreement with the result; most studies [7] showed that, applying herbicide or herbicide plus manual weeding was more economical than manual or hand weeding alone.

Table4. Cost benefit analysis

\begin{tabular}{|c|c|c|c|c|c|}
\hline No. & Treatment & $\begin{array}{c}\text { Grain yield } \\
\left(\mathrm{Kg} \mathrm{ha}^{-1}\right)\end{array}$ & $\begin{array}{c}\text { Gross return } \\
\left(\text { Birr ha }^{-1}\right)\end{array}$ & $\begin{array}{l}\text { Variable Cost } \\
\left(\text { Birr }^{-1} \mathbf{a}^{-1}\right)\end{array}$ & $\begin{array}{l}\text { Net returns } \\
\left(\text { Birr ha }^{-1}\right)\end{array}$ \\
\hline 1 & S-metolachlor $1.0 \mathrm{~L} \mathrm{ha}^{-1}$ & 2170 & 34720.00 & 2300.00 & 32420.00 \\
\hline 2 & S-metolachlor1.0 Lha $^{-1}+\mathrm{HW}$ & 2502 & 40032.00 & 3915.00 & 36117.00 \\
\hline 3 & S-metolachlor $1.5 \mathrm{~L} \mathrm{ha}^{-1}$ & 2080 & 33280.00 & 3450.00 & 29830.00 \\
\hline 4 & S-metolachlor $1.5 \mathrm{~L} \mathrm{ha}^{-1}+\mathrm{HW}$ & 2540 & 40640.00 & 5065.00 & 35575.00 \\
\hline 5 & HW X2 (25-30, 55-60) & 2770 & 44320.00 & 2145.40 & 42174.00 \\
\hline 6 & Untreated control & 975 & 15600.00 & & 15600.00 \\
\hline
\end{tabular}

Local market price of Faba bean $=16.00$ birr/kg grain, HW= hand weeding

Coast of 1 litre S-metolachlor $=(2300 \mathrm{Birr} / \mathrm{kg}$,

Coast of one man days $=30.00$ Birr

\section{CONCLUSION AND RECOMMENDATIONS}

Results of these study revealed that two hand weeding can be recommended in faba bean farms where labor power is not a problem. But under labor scarce conditions, pre-emergence application of lower rate of S-metolachlor $1.0 \mathrm{~L} \mathrm{ha}^{-1}$ supplemented with one hand weeding 4 to 5 weeks after crop emergence was found to be most effective in reducing the weed infestation and enhancing the seed yield of faba bean benefit cost ratio.

\section{ACKNOWLEDGEMENT}

The authors would like to acknowledge Ethiopian Institute Agricultural Research, Holetta Agricultural Research Center for financial support, field and facilities. Especial thanks are also extended to the Holetta weed science research program staffs for their assistance in conducting the experiment and data collection.

\section{REFERENCES}

[1] Haileslassie, A., Priess, J.A., Veldkamp, E. and Lesschen, J.P., 2006. Smallholders' soil fertility management in the Central Highlands of Ethiopia: implications for nutrient stocks, balances and sustainability of agroecosystems. Nutrient Cycling in Agroecosystems, 75(1-3), pp.135-146.

[2] Fesehaie, R., 1994. Weed research in cool-season food legumes. In 1. National Cool-season Food Legumes Review Conference, Addis Abeba (Ethiopia), 16-20 Dec 1993. ICARDA/IAR.

[3] Telaye, A., Bejiga, G. and Gerhe, A., 1994. Role of cool-season food legumes and their production constraints in Ethiopian agriculture. In 1. National Cool-season Food Legumes Review Conference, Addis Abeba (Ethiopia), 16-20 Dec 1993. ICARDA/IAR.

[4] Fessehaie, R., 1986. A review of weed science research activities in pulses in Ethiopia. In Proceedings of the First Ethiopian Crop Protection Symposium, Addis Ababa (Ethiopia), 4-7 Feb 1985. IAR.

[5] SAS Institute. SAS/STAT guide for personal computers, version 9.00 edition. Cary, NC: SAS Institute Inc. (2002)

[6] Jafari, R., Rezai, S. and Shakarami, J., 2013. Evaluating effects of some herbicides on weeds in field bean (Phaseolus vulgaris). International Research Journal of Applied and BasicSciences, 6(8), pp.1150-1152.

[7] Daba, N.A. and Sharma, J., 2018. Assessment of Integrated Weed Management Practices on Weed Dynamics, Yield Components and Yield of Faba bean (Vicia faba L.) in Eastern Ethiopia. Turkish Journal of Agriculture-Food Science and Technology, 6(5), pp.570-580

[8] Sajid, M., Rab, A., Jan, I., Ahmad, I., Ahmad Khan, I. and Anwar Khan, M., 2012. Effect of herbicides and row spacing on the growth and yield of pea. Pakistan Journal of Weed Science Research, 18(1).

[9] Wakweya, K. and Dargie, R., 2017. The Effect of Pre-emergence Herbicide (dual gold) and Hand Weeding Frequencies on Growth, Yield and Yield components of faba bean in Bale highlands. In Oromia Agricultural Research Institute, Workshop proceeding for completed research activities of Adaptation and Generation of Agricultural Technologies (p. 61). 
Efficacy and Selectivity of Pre-Emergence Herbicide S- Metolachlor Against Annual Grass and Broad Leaved Weeds in Faba Bean

[10] Getnet, K., Mekuria, W., Langan, S., Rivington, M., Novo, P. and Black, H., 2017. Ecosystem-based interventions and farm household welfare in degraded areas: Comparative evidence from Ethiopia. Agricultural Systems, 154, pp.53-62.

Citation: Kassahun Zewdie, Kiflom Yohannes, "Efficacy and Selectivity of Pre-Emergence Herbicide SMetolachlor Against Annual Grass and Broad Leaved Weeds in Faba Bean" International Journal of Research Studies in Agricultural Sciences (IJRSAS), 2019; 5(7), pp. 1-6, http://dx.doi.org/10.20431/24546224.0507001

Copyright: (C) 2019 Authors. This is an open-access article distributed under the terms of the Creative Commons Attribution License, which permits unrestricted use, distribution, and reproduction in any medium, provided the original author and source are credited. 